\title{
The Importance of Correlation of T-helper and T-supressor Limfocitary Subpopulations - Indicators of Animals Immune Status
}

\author{
Rita GOLBAN ${ }^{1}$ \\ ${ }^{1}$ The State Agrarian University of Moldova, Republic of Moldova. \\ *corresponding author: golbanrita@gmail.com \\ Bulletin UASVM Veterinary Medicine 75(2)/2018 \\ Print ISSN 1843-5270; Electronic ISSN 1843-5378 \\ doi:10.15835/buasvmcn-vm: 2018.0016
}

\begin{abstract}
:
The scientific investigations reflected in this study present the research in dynamics of the activity of correlating T-helper and T-suppressor immunocompetent cells at the newborn calves in different age periods. In the scientific research is presented the main effector role of these indicators, regarding the importance of the immune system through the ability to synthesize lymphokines, etc.

The researches reveal T-helper and T-suppressor level of lymphocytes at all research ages. Thus at 10 days the concentration of T-helper lymphocytes was $7.85 \pm 0.001$ and $8.30 \pm 0.08 ; 7.57 \pm 0.008$ at the age of 20 and 30 days, compared to T-suppressor lymphocytes, which in these age groups was equal to $6.0 \pm 0.08 ; 6.33 \pm 0.08$ and $6.0 \pm 0.08$.

The results of the investigations offer the possibility to understand that the correlation of some lymphocytary subpopulations of the newborn animal organism provides the possibility of installing a strong immunity and ensures the maintenance of the biochemical homeostasis of the organism.
\end{abstract}

Keywords: Cell Immunity, T-helper, T-suppressor, Lymphocytary Subpopulations.

\section{Introduction}

From the structural point of view, according to the modern conception, the immune system of superior organisms is considered as a diffused body, which consists of a very large number of molecules and cells, combined in a network of complex interactions, the function of which is to ensure the integrity and the structural individuality of the organism (Golban, 2015; Horhogea, 2015).

Cellular elements perform complex functions, both effector of the cell mediated immune response as well as regulator, by humoral factors that are secreted, it performs important functions determined by cells lysing which express nonself molecules on their surface; regulating the immune response; mediating delayed hypersensitivity reactions, etc. These functions are the result of functional heterogeneity and are due to the activation of distinct T-helper and T-suppressor subpopulations (Andrieş et al., 2014; Gâjâilă, 2002).

T-helper lymphocytes play an important role in cell mediated immune response, the activation of memory B lymphocytes, stimulation of humoral immune response, and the establishment of allergic states by their ability to induce IgE synthesis and to stimulate mast cells (Gâjâilă, 2003; Taşbac, 2014).

The Ts lymphocytes are inhibitors of the immune response amplitude after antigen depletion. They have the role of maintaining the intensity of the immune reactions within physiological limits. They exert a suppressive role on the immune response by inhibiting the 
activity of Th lymphocytes, but also have a direct suppressor effect on T and B effector lymphocytes. Simultaneously, Ts lymphocytes play an important role in inducing the state of tolerance to exogenous antigens as well as to selfmolecules (Brokaw, 2013; Rosen, 2008).

The purpose of selective immunosuppression is to maintain the functionality of the body's defense mechanisms against viral, bacterial, fungal and parasitic infections to maintain the ability of phagocytosis of aging cells, to protect immunosuppression mechanisms that remove malignant cells (Taşbac, 2014; Siloşi, 2014).

Themain objective of this study is to evidentiate the importance of correlation of T-Helper and T-Supressor limfocitary subpopulations and to analyze the immune status according to these indicators.

\section{Materials and methods.}

The investigations were performed in the laboratory of Veterinary Medicine of the State Agrarian University of Moldova and in the private laboratory „Synevo” from Chisinau. For performing the scientific investigations were used 24 blood samples of the new-born calves in order to determine the immunological indices of the immune status.

The samples of blood were collected from the jugular vein using anticoagulant in order to identify leukocytes, lymphocytes indices and $\mathrm{T}$ and $\mathrm{B}$ immunocompetent cells with their subpopulations.

The separation of $\mathrm{T}$ and $\mathrm{B}$ lymphocytes was performed by the spontaneous rosetting method. Was respected the manner of determining lymphocytes by contacting heterologous erythrocytes, which have formed complexes like rosettes, resulting from couplings between the major erythrocytesurface antigens and lymphocyte receptors. The formed "immune" rosettes were determined and highlighted by the subsequent lymphocytes, which formed "non-immune" rosettes with sheep erythrocytes, resulting from the interaction of antigenic determinants of erythrocytes with other lymphocyte membrane receptors than those involved in the immune recognition of effectors.

The T-lymphocytes were appreciated by the presence of the specific receptors towards ram's red cells, using the Erythrocyte rosetting
(E-rosetting) spontaneous rosette reaction and the $\mathrm{B}$ lymphocytes by the presence of the receptors against the complement active third component in the complementary rosette reaction of the Erythrocyte antibody complement rosetting EACrosetting. Concomitantly from heparinized blood were performed smears, which were fixed with methyl alcohol and stained for 8-10 minutes after the Romanovschii-Giemsa method (manufacturer Biolab). After calculating the leukocyte number and their determination, were evaluated the leukocyte formula and the lymphocyte percent.

The rossetted lymphocytes were distinguished by placing around them of three markers who joined the surface.

\section{Results and discussions}

The results of immunological investigations regarding the immune system on the correlation of T-helper and T-suppressor lymphocyte subpopulations - important indicators of animal immune status, demonstrate that the level of immune indices correlates and highlights important values.

According to the studies, the leukocyte and lymphocyte levels vary at different age stages of the newborn animals (Table 1). Significant results of the white blood cell indices were determined at cattle, aged of 10,20 and 30 days, the results being equal to $7.90 \pm 0.81$ compared to values obtained from calves of 20 and 30 days, where the indices were equal to $6,95 \pm 0.81$ and $7.35 \pm 0.81$.

At the same time, was determined the number of lymphocytes at the newborn animals, which shows appreciable values at the age of 10 days compared to the age of 20 and 30 days was equal to $3.71 \pm 0.1$ and $3.90 \pm 0.3$ and $3,31 \pm 0.40$.

By contacting his protection apparatus, the organism triggers reactions against what is nonself for the cells of this device, causing either an immunological hypersensitivity reaction or a simple immune reaction (Horhogea, 2015).

However, the immune defense mechanisms by which it influences the animal organism are not still sufficiently elucidated, therefore the immune response is considered as a protection mechanism by which the organism recognizes what is foreign to itself. Recognition of self by the distinction of non-self is very precise and specific to each organism. Among the mechanism that generates illness or favors chronicising an important role is played by the disturbance of immune response. 
Table 1. The level of leukocytes and lymphocytes at the new-born calves in dependance of age (\%)

\begin{tabular}{ccc}
\hline Age & Leukocyte & Lymphocyte \\
\hline $\begin{array}{c}\mathrm{n}=6 \\
10\end{array}$ & $7,90 \pm 0,81$ & $3,71 \pm 0,1$ \\
\hline 20 & $6,95 \pm 0,81$ & $3,90 \pm 0,3$ \\
\hline 30 & $7,35 \pm 0,81$ & $3,31 \pm 0,40$ \\
\hline
\end{tabular}

Table 2.The level of T-helper and T-suppressor at the newborn calves depending on age (\%)

\begin{tabular}{ccc}
\hline Age & T-helper & T-supresor \\
\hline $\begin{array}{c}\mathrm{n}=6 \\
10\end{array}$ & $7,85 \pm 0,001$ & $6,0 \pm 0,08$ \\
\hline 20 & $8,30 \pm 0,08$ & $6,33 \pm 0,08$ \\
\hline 30 & $7,57 \pm 0,008$ & $6,0 \pm 0,08$ \\
\hline
\end{tabular}

The Table 2 reveals T-helper and T-suppressor lymphocytes at all research ages. Thus at 10 days the concentration of T-helper lymphocytes was $7.85 \pm 0.001$ and $8.30 \pm 0.08 ; 7.57 \pm 0.008$ at the age of 20 and 30 days, compared to T-suppressor lymphocytes, which in these age groups were equal to $6.0 \pm 0.08 ; 6.33 \pm 0.08$ and $6.0 \pm 0.08$.

Therefore, referring to the aspects of correlation, we mention that $\mathrm{T}$ helper secretes lymphokine, including interferon and interleukins. Limfokines are stimulatory molecules that determines the Th cells to clone and other immune cells to perform their functions. In this order of ideas, Th cells stimulate macrophages for phagocytosis and B cells to produce antibodies. This mechanism deduces a resulting clone containing $\mathrm{T}$ suppressor (Ts) cells and $\mathrm{T}$ cells with memory (TM). Formation of an appropriate number of Ts cells leads to slowing the immune response (Andrieș et al., 2014).

Regarding T-suppressor cells, it is known that they are capable of depressing both the function of Tc cells and Th cells. It is believed that this role of depression serves to regulate the activity of other cells, which avoids excessive immune reactions that could cause severe disorders in the body (autoimmune diseases) (Siloşi, 2014).

At the same time, the factors involved in immunocorrelation are very numerous. Some of these correlate with the antigen, with the type and amount of antibodies.

Such research conducted to determine lymphocyte subpopulations correlation characteristics of calves from birth until the age of 30 days allowed us to make some conclusions in the emergence and development of cellular and humoral immunity (Brokaw, 2013). Thus, the main factor of cellular immunity is the $\mathrm{T}$ and $\mathrm{B}$ lymphocytes with the respective subpopulations, which determine the immune reactions of the body, which favor immunocompetence of the lymphoid cells and regulate the immune system (Golban, 2015).

Therefore, at all age periods, starting with the 10th day of life and up to the 30th day of life, significant values of T-cell lymphocyte indices were determined, which allows us to conclude that the immunological reactivity of the newborn organism takes place and the adaptation to changes take place in the environment conditions (Rosen, 2008).

\section{Conclusion}

The immunological investigations demonstrated that at the newborn animals in certain growth and developmental periods gradually, the values of T-helper and T-suppressor lymphocytic subpopulations reveals important correlations of 
the cells reactions, determined by the organism processes of defence.

The leukocytes indices at the cattle aged of 10 , 20 and 30 days, determined values equal to $7.90 \pm$ 0.81 compared to values obtained from calves of 20 and 30 days, where the indices were equal to 6 , $95 \pm 0.81$ and $7.35 \pm 0.81$.

The correlation mechanism of the level of T-helper and T-supressor at all ages of research reveal that at the age of 10 days the concentration of T-helper lymphocytes was $7.85 \pm 0.001$ and $8.30 \pm 0.08 ; 7.57 \pm 0.008$ at the age of 20 and 30 days, compared to T-suppressor lymphocytes, which in these age groups were equal to $6.0 \pm 0.08$; $6.33 \pm 0.08$ and $6.0 \pm 0.08$.

Acknowledgments. This research did not receive any specific grant from funding agencies in the public, commercial, or not-for-profit sectors.

\section{References}

1. Andrieș L, Barba D, Cernețchi O, Stratan V (2014). Imunologie clinică. Chişinău: Editura Tipografia Centrală. $556 \mathrm{p}$.

2. Brokaw A (2013).Immunology: Use Howard Hughes Medical Institute Resurces to Teach. Ohio. 37 p. Disponibil: http: // www.hhmi.org/ biointeractive/ teacher-guideimmunologzy.

3. Gâjâilă G (2002). Imunologie analitică. Aspecte fundamentale şi metodologice. București Editura Printech. 224p

4. Gâjâilă G (2003). Sistemul imunitar la suine. București, Editura Cartea Universitară. 131 p.

5. Golban R (2015). Imunologie şi imunopatologie. Curs de prelegeri, Chișinău, uasm.moodle.md ,UASM, 155p., 4,8 c.a.

6. Horhogea C (2015). Imunologie și imunopatologie. Iaşi:Editura „Ion Ionescu de la Brad”. 164 p.

7. Rosen RH (2008). Transplantation Immunology: Whatthe Clinician Needs to Know for Immunotherapy Gastroenterology,134:1789-180.

8. Tașbac A (2014).Îndrumar pentru laboratorul de imunologie veterinară. București: Larisa, Câmpulung Muscel, 170p.

9. Siloşi I (2014). Imunologie. Craiova: Editura SITECH. 266p. 